\title{
Aplikasi Augmented Reality Penuntun Shalat Untuk Anak Usia Dini
}

\author{
Ramdan Adjis ${ }^{1}$, Vivi P. Rantung 2 , Sondy Kumajas ${ }^{3}$, Gladly C. Rorimpandey ${ }^{4}$ \\ Program Studi Teknik Informatika UNIMA \\ Email: ramdanadjis98@gmail.com
}

\begin{abstract}
This prayer guide Augmented Reality application is designed for early childhood with parental supervision. The purpose of developing this application is to give new experiences for early childhood in learning prayer with technology of Augmented Reality Application. The method used is Multimedia Development Life Cycle (MDLC) wich consists of six stages, namely Concept, Design, Material Collection, Assembly, Testing, and Distribution. After the application development process, the result of this research is an Augmented Reality Application that is used by early childhood in learning prayer using a Smartphone.
\end{abstract}

Keywords : Augmented Reality, MDLC, Mobile Application.

\begin{abstract}
Abstrak - Aplikasi Augmented Reality Penuntun Shalat ini dirancang untuk anak usia dini dengan pengawasan orangtua. Tujuan pengembangan aplikasi adalah memberikan pengalaman baru untuk anak usia dini dalam belajar gerakan Shalat dengan menerapkan teknologi Augmented Reality. Metode yang digunakan dalam pengembangan aplikasi ini adalah Multimedia Development Life Cycle (MDLC) yang terdiri dari enam tahapan, yaitu Concept, Design, Material Collection, Assembly, Testing, dan Distribution. Setelah proses pengembangan aplikasi, hasil dari penelitian adalah sebuah Aplikasi Augmented Reality Penuntun Shalat yang dapat anak usia dini belajar gerakan Shalat dengan menggunakan Smartphone.
\end{abstract}

Kata Kunci : Augmented Reality, MDLC, Mobile Application.

\section{PENDAhuluan}

Shalat sebagai ibadah adalah salah satu media manusia untuk berkomunikasi dengan sang pencipta. Disamping itu, poin kedua dalam rukun islam ini merupakan ibadah amalia seorang hamba kepada Tuhan-Nya dalam rangka untuk mendekatkan diri. Didalam ajaran agama Islam, ibadah shalat menduduki tempat tertinggi dibandingkan dengan ibadah lainnya. Oleh karena itu lebih baik untuk belajar mengenai shalat dari usia kanak - kanak [1].

Media pembelajaran mengenai tata cara shalat beserta wudhu saat ini banyak ditemui dipasaran, seperti buku. Buku penyampaian tuntunan shalat dan wudhu hanya berupa teks atau gambar diam saja[1]. Bagi anak-anak, buku-buku tuntunan shalat yang statis tidak memberikan fasilitas contoh gerakan-gerakan dalam shalat yang jelas dan diperlihatkan secara baik dan benar. Oleh karena itu sangat dibutuhkan alat bantu ajar yang dinamis dan menarik yang dapat memberikan contoh gerakan shalat[2].

\section{TINJAUAN PUSTAKA}

\section{A. Aplikasi}

Aplikasi adalah program siap pakai yang dapat digunakan untuk menjalankan perintah-perintah dari pengguna aplikasi tersebut dengan tujuan mendapatkan hasil yang lebih akurat sesuai dengan tujuan pembuatan aplikasi tersebut, aplikasi mempunyai arti yaitu pemecahan masalah yang menggunakan salah satu Teknik pemrosesan data aplikasi yang biasanya berpacu pada sebuah komputansi yang diinginkan atau diharapkan maupun pemrosesan data yang diharapkan [3].

\section{1) Blender}

Blender adalah salah satu software open source yang digunakan untuk membuat konten multimedia khusunya 3Dimensi , ada beberapa kelebihan yang dimiliki Blender dibandingkan software sejenis.

\section{2) Unity $3 D$}

Unity adalah salah satu game engine yang banyak digunakan. Dengan software ini, membuat game sendiri dapat dilakukan dengan lebih mudah dan cepat. Hebatnya lagi, unity mensuport pembuatan game dalam berbagai platform, misal Unity Web, Windows, Mac, Android, iOS, XBox, Playstation 3 dan Wii [4].

B. Augmented Reality

Augmented Reality yaitu teknologi interaksi dimana dunia nyata (real time) dengan dunia maya (virtual world) yang di gabungkan[5][6]. 
C. Shalat

Menurut arti bahasa shalat adalah doa. Secara terminologi syara' merupakan sekumpulan ucapan dan perbuatan dengan di awali takbir dan di akhiri dengan salam. Ia dikatakan shalat karena menghubungkan seorang hamba kepada penciptanya, serta shalat juga merupakan manifestasi penghambaan dan kebutuhan diri kepada Allah SWT.

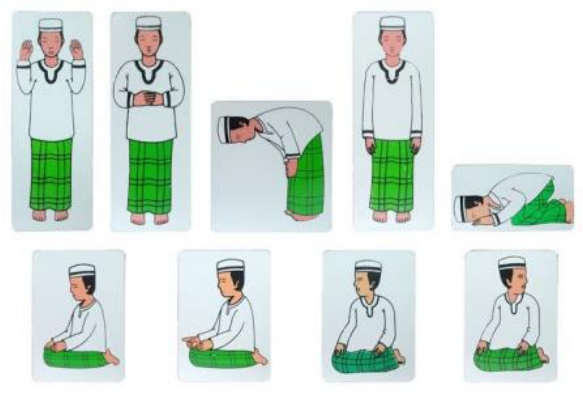

Gbr. 1 Gerakan Shalat.

D. Android

Android merupakan sistem operasi berbasis linux yang digunakan untuk perangkat mobile seperti smartphone dan komputer tablet. Android juga mencakup sistem operasi, middleware dan aplikasi yang menyediakan platform terbuka untuk bagi para pengembang untuk menciptakan aplikasi lainya $[6][7][8]$.

\section{TINJAUAN PUSTAKA}

A. Model Pengembangan Sistem

Prosedur penelitian merupakan kerangka kerja yang digunakan dalam melaksanakan penelitian [5]. Metode pengembangan sistem yang digunakan dalam penelitian ini yaitu metode model Multimedia Development Life Cycle ini terdiri dari Concept (Konsep), Design (Desain / Perancangan), Material Collecting (Pengumpulan Materi), Assembly (Penyusunan dan Pembuatan), Testing (Uji Coba) dan Distribution (Menyebarluaskan) [9].

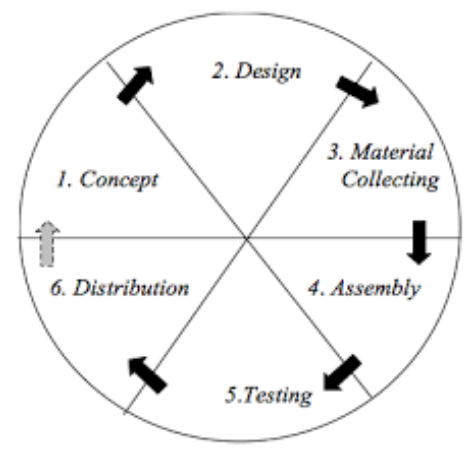

Gbr. 2 Model Pengembangan MDLC

B. Teknik Pengumpulan Data

Dalam Proses penelitian ini, membutuhkan data yang benar-benar akurat, relevan valid dan reliable sehingga mendapat hasil yang diharapkan. Oleh karena itu peneliti melakukan riset terlebih dahulu untuk mengumpulkan data-data informasi dengan cara seperti berikut :

\section{Observasi}

Peneliti melakukan observasi untuk penelitian ini dengan mengamati dan melihat secara langsung bagaimana proses pembelajaran tata cara shalat kepada anak usia dini di RA Arafah Bitung.

\section{Wawancara}

Peneliti juga melakukan wawancara kepada salah satu tenaga pengajar di RA Arafah Bitung, tentang bagaimana cara proses pembelajaran tata cara shalat kepada anak usia dini.

\section{HASIL DAN PEMBAHASAN}

\section{A. Concept.}

Dalam tahap ini peneliti mulai membuat konsep dari aplikasi yang akan dibuat dan menganalisis kebutuhan yang akan dibangun sistem, dan hasil dari tahapan ini adalah deskripsi konsep aplikasi dan konsep dasar aplikasi.

TABEL I. DESKRIPSI KONSEP

\begin{tabular}{|l|l|}
\hline \multicolumn{1}{|c|}{$\begin{array}{c}\text { Kategori } \\
\text { Konsep }\end{array}$} & \multicolumn{1}{c|}{ Deskripsi Konsep } \\
\hline Judul & $\begin{array}{l}\text { Aplikasi Augmented Reality Penuntun } \\
\text { Shalat Untuk Anak Usia Dini. }\end{array}$ \\
\hline Nama Aplikasi & Mari Belajar Shalat. \\
\hline $\begin{array}{l}\text { Jenis } \\
\text { Multimedia }\end{array}$ & $\begin{array}{l}\text { Media informasi Penuntun Shalat berbasis } \\
\text { multimedia interaktif berbentuk sebuah } \\
\text { aplikasi yang menggunakan teknologi } \\
\text { Augmented Reality. }\end{array}$ \\
\hline Tujuan & $\begin{array}{l}\text { Membuat dan mengimplementasikan } \\
\text { teknologi Augmented Reality pada Aplikasi } \\
\text { Penuntun Shalat. Diharapkan aplikasi ini } \\
\text { dapat meningkatkan daya tarik anak usia } \\
\text { dini akan pentingnya belajar Shalat dan juga } \\
\text { meningkatkatn penyampaian informasi } \\
\text { yang lebih interaktif. }\end{array}$ \\
\hline Sasaran & Anak usia dini \\
\hline Video & Video konten berbentuk montion graphics \\
\hline Gambar & $\begin{array}{l}\text { Macksound dan audio effect, dengan format } \\
\text { audio (*.wav dan *mp3) }\end{array}$ \\
\hline Audio &
\end{tabular}

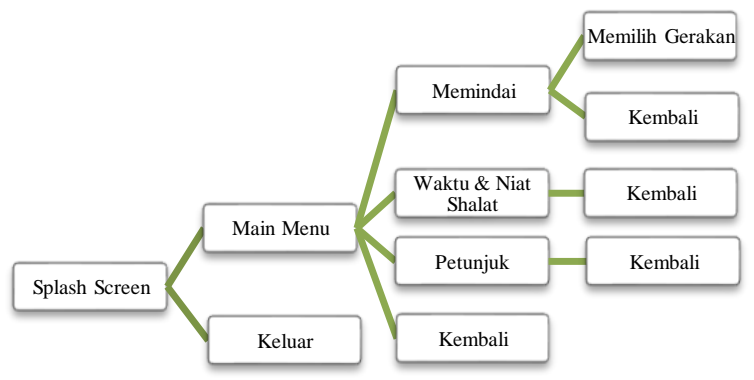

Gbr. 3 Konsep Dasar Aplikasi. 


\section{B. Design.}

Setelah tahap Concept selesai, tahap selanjutnya adalah tahap perancangan aplikasi. Pada tahap ini peneliti akan memulai perancangan aplikasi dalam bentuk flowchart, storyboard dan desain struktur navigasi berupa hirarki menu.

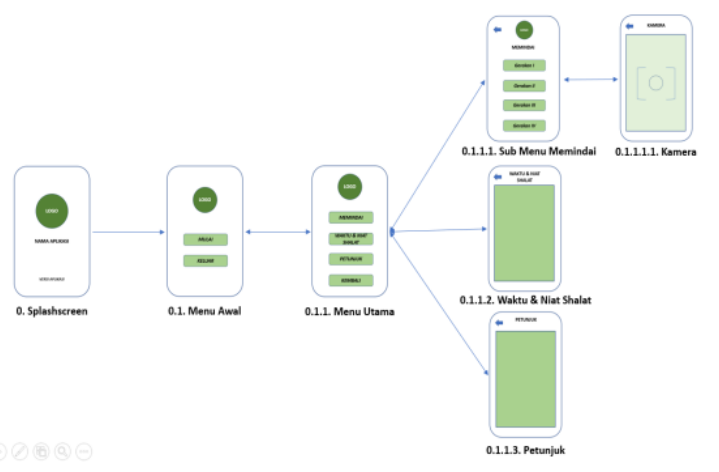

Gbr. 4 Hirarki Storyboard.

TABEL III. TABEL STORYBOARD.

\begin{tabular}{|c|c|c|}
\hline No & Tampilan & Deskripsi \\
\hline 1 & URES NeV & $\begin{array}{l}\text { 0. Splash Screen : } \\
\text { Pada tampilan ini adalah awal } \\
\text { tampilan dari aplikasi yang } \\
\text { berdurasi 5 detik dan } \\
\text { menampilkan Logo aplikasi, nama } \\
\text { aplikasi, versi pembuatan, setelah } \\
\text { itu akan diarahkan ke tampilan } \\
\text { Main Menu. } \\
\text { Navigasi : } \\
\text { - 'Splash Screen' > 'Main Menu' }\end{array}$ \\
\hline 2 & mowa & $\begin{array}{l}\text { 0.1.Main Menu : } \\
\text { Tampilan ini adalah tampilan } \\
\text { Main Menu dari aplikasi yang } \\
\text { dimana menampilkan Logo } \\
\text { aplikasi dan tersedia } 2 \text { fitur yakni } \\
\text { Mulai dan Keluar. } \\
\text { Navigasi Tombol : } \\
\text { - Mulai ('Main Menu' > 'Menu' ) } \\
\text { - Keluar ( Keluar dari Aplikasi) }\end{array}$ \\
\hline 3 & 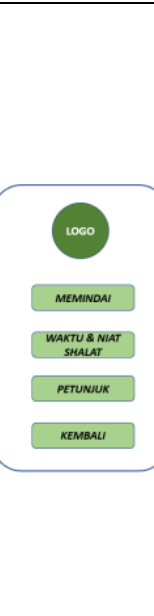 & $\begin{array}{l}\text { 0.1.1.Menu : } \\
\text { Pada tampilan ini adalah tampilan } \\
\text { menu aplikasi menampilkan Logo } \\
\text { aplikasi, dan tersedia } 4 \text { fitur yakni } \\
\text { Memindai, Waktu \& Niat Shalat, } \\
\text { Petunjuk dan Kembali. } \\
\text { Navigasi Tombol : } \\
\text {-Memindai ( Tampilan 'Menu' > } \\
\text { Tampilan 'Memindai' ) } \\
\text {-Waktu \& Niat Shalat ( Tampilan } \\
\text { 'Menu' > Tampilan 'Waktu \& } \\
\text { Niat Shalat' ) } \\
\text { - Petunjuk ( Tampilan 'Menu' > } \\
\text { Tampilan 'Petunjuk' ) } \\
\text { - Kembali (Tampilan 'Menu' > } \\
\text { Tampilan 'Main menu' / Kembali } \\
\text { ke tampilan sebelumnya). }\end{array}$ \\
\hline
\end{tabular}

\begin{tabular}{|c|c|c|}
\hline No & Tampilan & Deskripsi \\
\hline 4 & Gerotan! & $\begin{array}{l}\text { 0.1.1.1. Memindai : } \\
\text { Pada tampilan ini adalah tampilan } \\
\text { sub menu memindai menampilkan } \\
\text { tombol dari gerakan-gerakan yang } \\
\text { akan di pindai pada marker. } \\
\text { Navigasi Tombol : } \\
\text { - Tanda Panah Kekiri ( Tampilan } \\
\text { 'Memindai' > Tampilan 'Main } \\
\text { Menu' / Kembali ke tampilan } \\
\text { sebelumnya). } \\
-\quad \text { Gerakan I ( Tampilan } \\
\text { 'Memindai'> Tampilan 'kamera') } \\
\text { - Gerakan II ( Tampilan } \\
\text { 'Memindai'> Tampilan 'kamera') } \\
\text { - Gerakan III ( Tampilan } \\
\text { 'Memindai'> Tampilan 'kamera') } \\
\text { - Gerakan IV ( Tampilan } \\
\text { 'Memindai'> Tampilan 'kamera') }\end{array}$ \\
\hline 5 & $=\quad$ ramera & $\begin{array}{l}\text { 0.1.1.1.1. Kamera : } \\
\text { Pada tampilan memindai, aplikasi } \\
\text { akan mengakses kamera pada } \\
\text { perangkat dan juga tersedia } \\
\text { tombol untuk Kembali (Tanda } \\
\text { Panah Kekiri). Pada tampilan ini } \\
\text { kamera akan mulai memproses } \\
\text { dan menampilkan objek } \\
\text { Augmented Reality. } \\
\text { Navigasi Tombol : } \\
\text { - Tanda Panah Kekiri ( Tampilan } \\
\text { 'Kamera' > Tampilan 'Memindai/ } \\
\text { Kembali ke tampilan } \\
\text { sebelumnya). }\end{array}$ \\
\hline 6 & 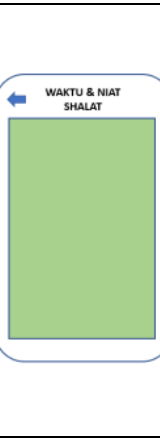 & $\begin{array}{l}\text { 0.1.1.2. Waktu dan Niat Shalat: } \\
\text { Pada tampilan ini akan } \\
\text { menampilkan informasi - } \\
\text { informasi tentang waktu dan juga } \\
\text { niat dari setiap shalat. Tampilan } \\
\text { ini juga tersedia tombol untuk } \\
\text { kembali (Tanda Panah Kekiri). } \\
\text { Navigasi Tombol : } \\
\text { - Tanda Panah Kekiri ( Tampilan } \\
\text { 'Memindai' > Tampilan 'Main } \\
\text { Menu' / Kembali ke tampilan } \\
\text { sebelumnya). }\end{array}$ \\
\hline 7 & $\leftarrow$ Petru & $\begin{array}{l}\text { 0.1.1.3. Petunjuk : } \\
\text { Pada tampilan ini akan } \\
\text { menampilkan informasi tentang } \\
\text { petunjuk penggunaan aplikasi dan } \\
\text { juga informasi dari pengembang } \\
\text { aplikasi. Tampilan ini juga } \\
\text { tersedia tombol untuk kembali } \\
\text { (Tanda Panah Kekiri). } \\
\text { Navigasi Tombol : } \\
\text { - Tanda Panah Kekiri ( Tampilan } \\
\text { 'Memindai' > Tampilan 'Main } \\
\text { Menu' / Kembali ke tampilan } \\
\text { sebelumnya). }\end{array}$ \\
\hline
\end{tabular}




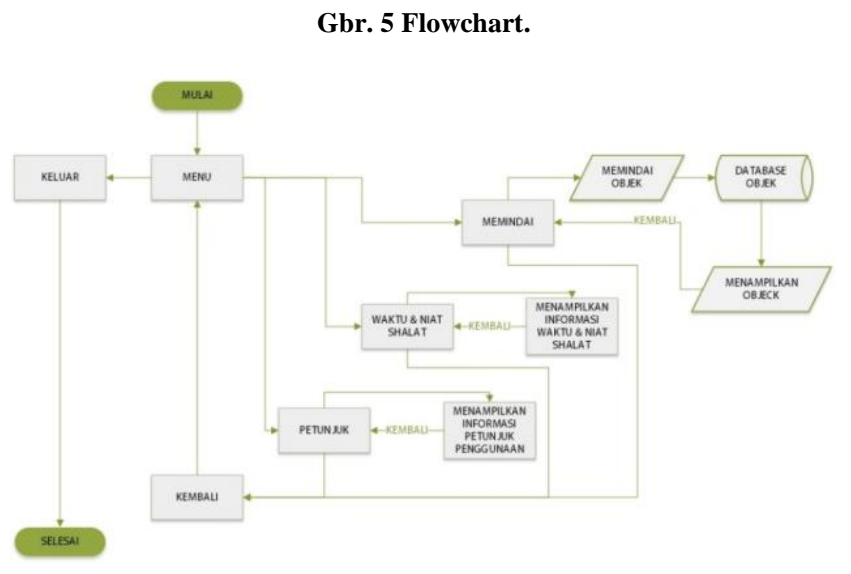

C. Material Collecting.

Pada tahap ini, peneliti telah mengumpulkan materi dan bahan-bahan yang sesuai dengan aplikasi seperti image, animation, music dan video. Diambil dengan cara pembuatan sendiri maupun mengambil dari berbagai sumber.

\section{Assembly.}

Untuk Proses pembuatan pada aplikasi Augmented Reality Penutun Shalat anak usia dini ini terdapat beberapa langkah yaitu pembuatan objek 3 demensi dan pembuatan aplikasi Augmented Reality. Hasil dari tahapan ini adalah aplikasi.

\section{Perancangan Objek 3D}

Dalam pembuatan Objek 3D karakter muslim, peneliti menggunakan aplikasi Blender, dan untuk format yang dihasilkan adalah ".blend". Pada proses ini terdapat beberapa proses, yaitu dari proses pemodelan objek, pemasangan bone pada objek, pembuatan skin pada objek, dan reggeng objek dengan enam gerakan. Dan proses reggeng ini terdapat enam gerakan yaitu Talbiratul Ikhram, Rukuk, Sujud, Duduk diantara dua Sujud, Tasyahud Akhir dan Salam.

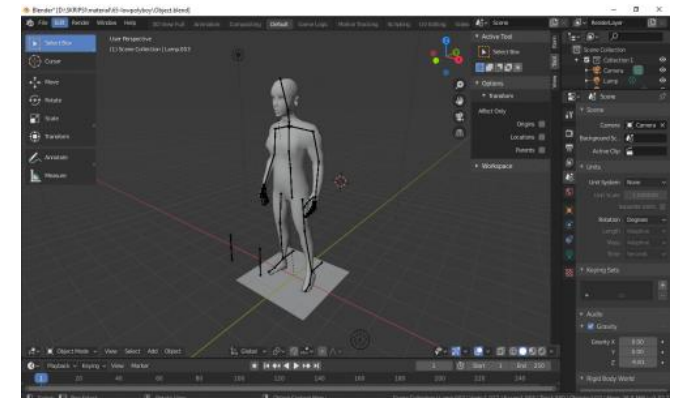

Gbr. 6 Proses Pemodelan Objek dan Pemasangan Bone.

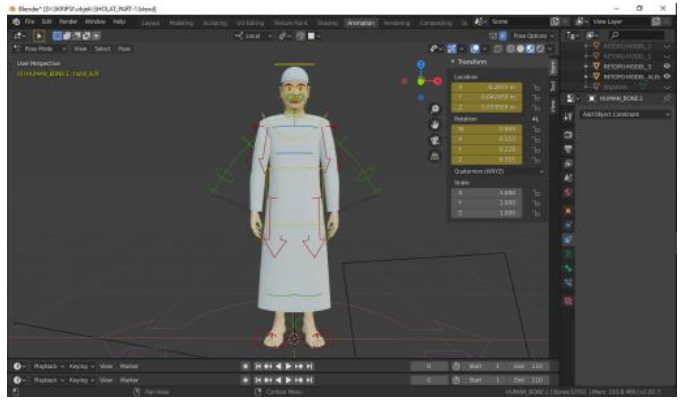

Gbr. 7 Proses Pembuatan Skin.

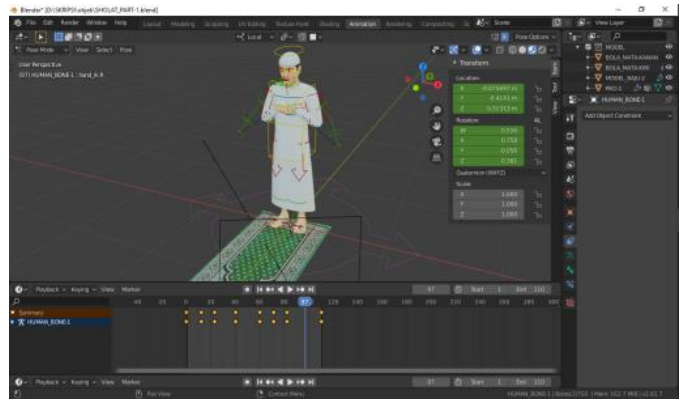

Gbr. 8 Proses Reggeng Objek.

2. Perancangan Aplikasi Augmented Reality.

Setelah melalui tahapan perancangan objek, selanjutnya adalah proses tahapan pembuatan aplikasi Augmented Reality dengan menggunakan aplikasi Unity. Berikut ini adalah proses pembuatan aplikasi Augmented Reality.

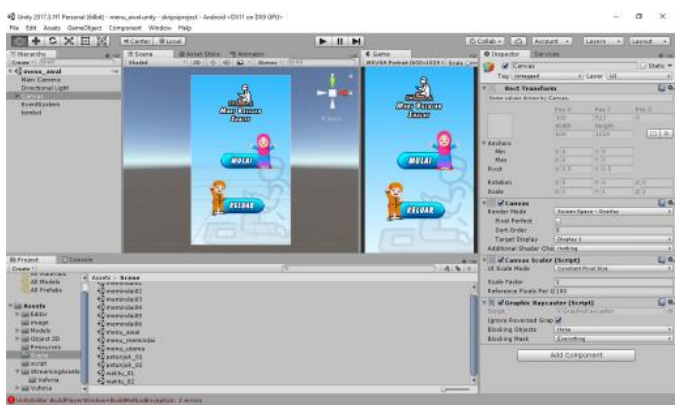

Gbr. 9 Pembuatan Menu Awal.

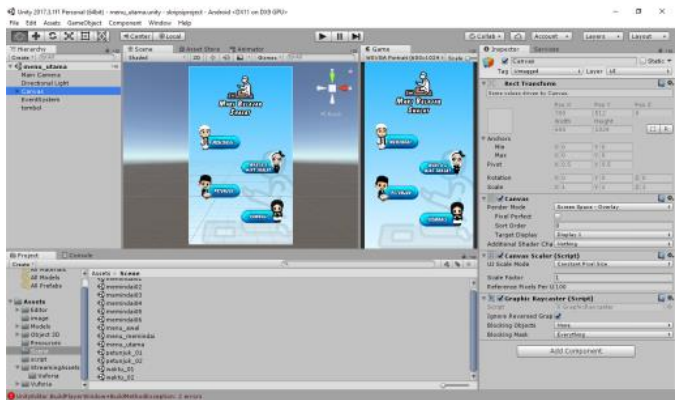

Gbr. 10 Pembuatan Menu Utama. 


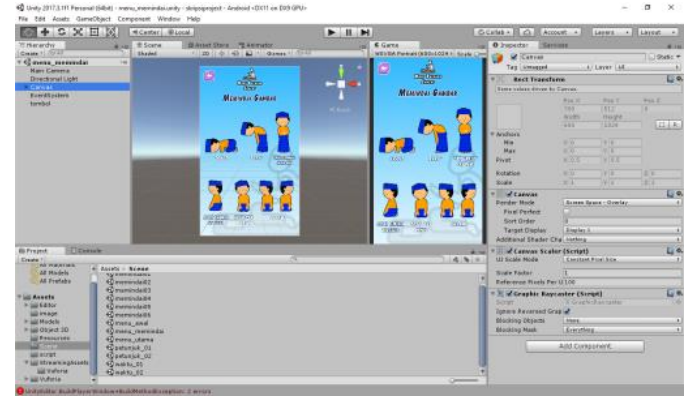

Gbr. 11 Pembuatan Sub Menu Memindai.

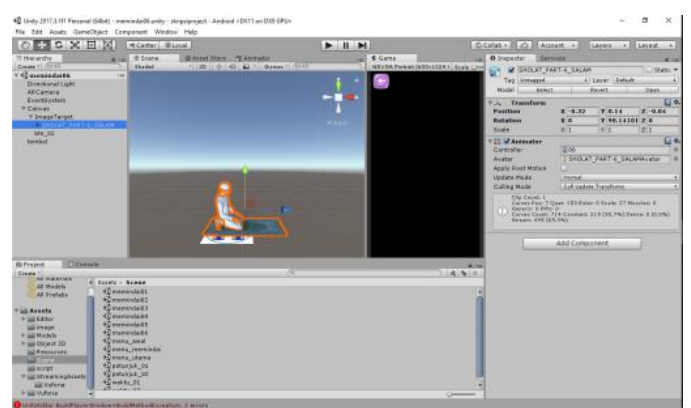

Gbr. 12 Pembuatan AR Camera pada Objek.

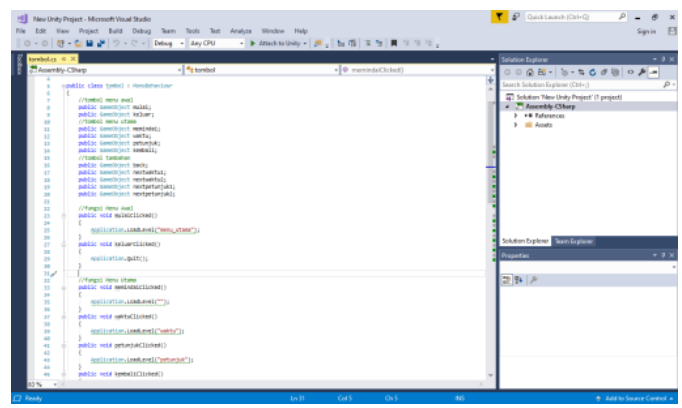

Gbr. 13 Proses Pengkodean.

3. Hasil Tampilan Aplikasi

Setelah melalui serangkaian tahapan pembuatan aplikasi Augmented Reality, berikut ini adalah tampilan-tampilan dari aplikasi yang telah dikembangkan bisa dilihat pada tabel II.

TABEL IIIII. TAMPILAN APLIKASI.

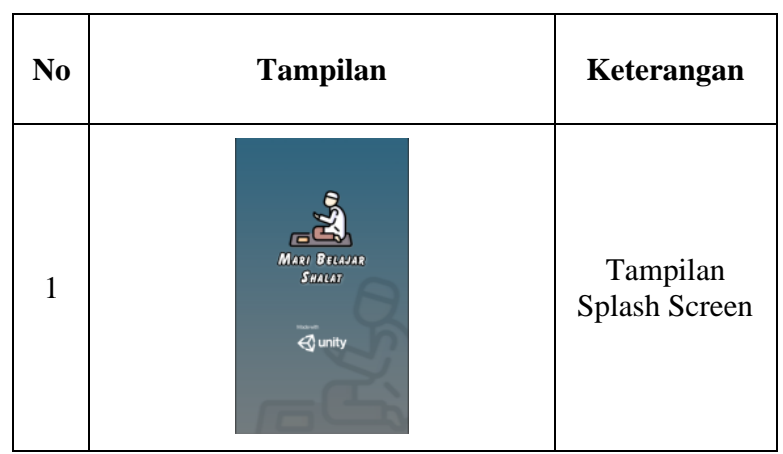

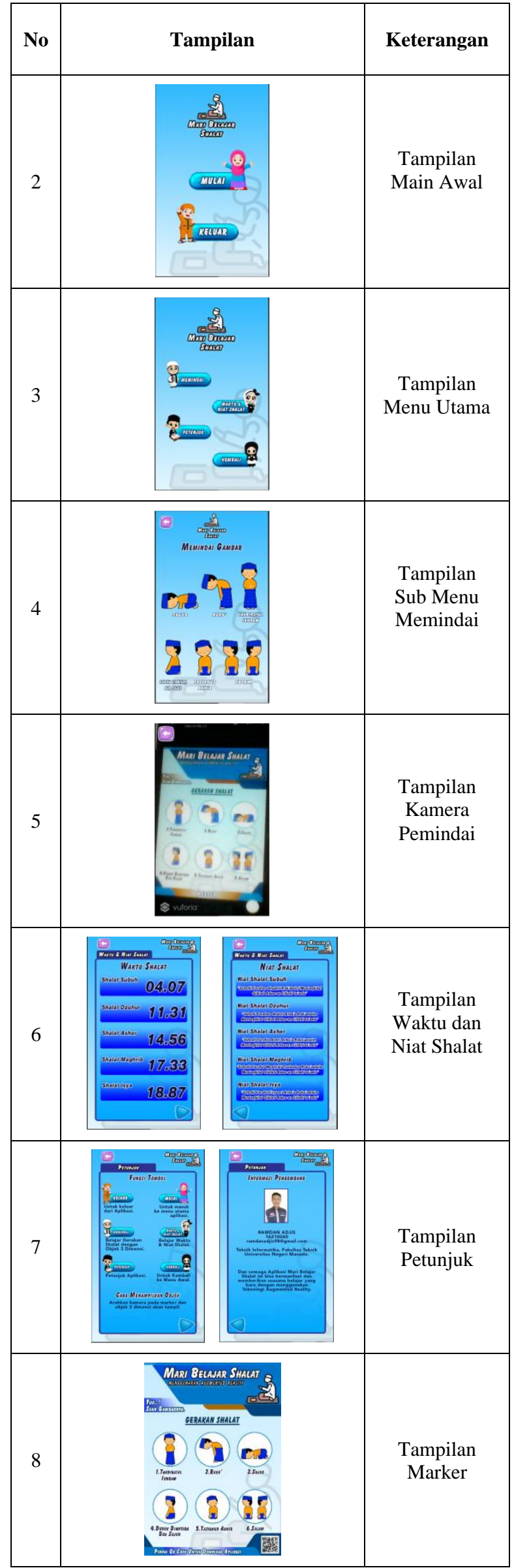




\section{E. Testing.}

Tahapan selanjutnya adalah tahapan pengujian. Pada tahap pengujian menggunakan Metode blackbox. Tujuan dari metode pengujian blackbox ini adalah untuk menemukan kesalahan pada program. Hasil dari tahapan ini adalah hasil dari testing yang dimana semua fitur dalam aplikasi berjalan sesuai perancangan.

Untuk pengujian aplikasi Mari Belajar Shalat ini juga dilakukan pengujian pada beberapa smartphone, berikut ini adalah table dari pengujian tersebut.

Tabel IIVi. Pengujian Smartphone.

\begin{tabular}{|c|c|c|}
\hline No & Device dan Spesifikasi & Hasil \\
\hline 1 & $\begin{array}{l}\text { Realme 5i } \\
\text { Sistem Operasi : } \\
\text { Android 10 } \\
\text { Layar : } 6.5 \text { " } \\
\text { Resolusi : 720x1600 } \\
\text { Pixel, Rasio 20:9 } \\
\text { Kamera : } 12 \text { Mega } \\
\text { Pixel. }\end{array}$ & $\begin{array}{l}\text { Aplikasi bisa berjalan } \\
\text { pada smartphone ini dan } \\
\text { fitur dari aplikasi } \\
\text { berjalan sesuai } \\
\text { perencangan awal. } \\
\text { Adapun kekurangan } \\
\text { yakni tampilan aplikasi } \\
\text { tidak responsible pada } \\
\text { layar atas dan bawah } \\
\text { smartphone, } \\
\text { dikarenakan smartphone } \\
\text { ini memiliki rasio layar } \\
\text { yang sedikit panjang } \\
\text { (20:9). }\end{array}$ \\
\hline 2 & $\begin{array}{l}\text { Redmi 4x } \\
\text { Sistem Operasi : } \\
\text { Android 6.1 } \\
\text { Layar : 5" } \\
\text { Resolusi : 20x1280 } \\
\text { Pixel, Rasio 16:9 } \\
\text { Kamera : 13 Mega } \\
\text { Pixel. }\end{array}$ & $\begin{array}{l}\text { Aplikasi bisa berjalan } \\
\text { pada smartphone ini dan } \\
\text { fitur dari aplikasi } \\
\text { berjalan sesuai } \\
\text { perencangan awal. } \\
\text { Adapun kekurangan } \\
\text { yakni tampilan aplikasi } \\
\text { tidak responsible pada } \\
\text { layar kiri dan kanan } \\
\text { smartphone, } \\
\text { dikarenakan smartphone } \\
\text { ini memiliki rasio layar } \\
\text { yang sedikit lebar } \\
\text { (16:9). }\end{array}$ \\
\hline 3 & $\begin{array}{l}\text { Redmi } 9 \\
\text { Sistem Operasi : } \\
\text { Android } 10 \\
\text { Layar : } 6.53 \text { " } \\
\text { Resolusi : 1080x2340 } \\
\text { Pixel, Rasio 19,5:9 } \\
\text { Kamera : } 13 \text { Mega } \\
\text { Pixel. }\end{array}$ & $\begin{array}{l}\text { Aplikasi bisa berjalan } \\
\text { pada smartphone ini dan } \\
\text { fitur dari aplikasi } \\
\text { berjalan sesuai } \\
\text { perencangan awal. } \\
\text { Adapun kekurangan } \\
\text { yakni tampilan aplikasi } \\
\text { tidak responsible pada } \\
\text { layar atas, bawah, kiri } \\
\text { dan kanan smartphone, } \\
\text { dikarenakan smartphone } \\
\text { ini memiliki resolusi } \\
\text { layar yang besar } \\
\text { (1080x2340 Pixels) dan } \\
\text { rasio layar yang sedikit } \\
\text { Panjang (19,5:9) } \\
\text { sehingga tampilan } \\
\text { terlihat kecil. }\end{array}$ \\
\hline 4 & $\begin{array}{l}\text { Vivo Y97 } \\
\text { Sistem Operasi : } \\
\text { Android } 8.1 \\
\text { Layar : 6" }\end{array}$ & $\begin{array}{l}\text { Aplikasi bisa berjalan } \\
\text { pada smartphone ini dan } \\
\text { fitur dari aplikasi } \\
\text { berjalan sesuai } \\
\text { perencangan awalm dan }\end{array}$ \\
\hline
\end{tabular}

\begin{tabular}{|l|l|l|}
\hline No & Device dan Spesifikasi & \multicolumn{1}{c|}{ Hasil } \\
\hline & Resolusi : 720x1440 & untuk resolusi \\
& Pixel, Rasio 18:9 & smartphone nya sesuai \\
& Kamera : 13 Mega & dengan tampilan aplikasi \\
& Pixel. & dengan resolusi \\
& & 720x1440 Pixels. \\
\hline
\end{tabular}

Kesimpulan dari pengujian aplikasi pada beberapa smartphone adalah aplikasi bisa berjalan lancer sesuai fitur dan AR bisa terdeteksi dan tampilan aplikasi yang tidak responsible pada smartphone yang tidak beresolusi 720x1440 Pixels dan Rasio 18:9.

\section{F. Distribution}

Tahapan distribusi adalah tahapan menyebarluaskan aplikasi. Cara yang digunakan dengn cara membagikan selebaran marker, dimana marker tersebut sudah terdapat Qrcode untuk discan dan akan diarahkan link download dari googledrive.

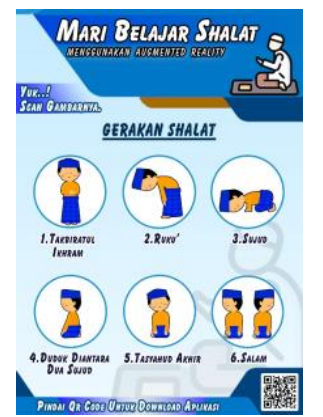

Gbr. 13 Marker Aplikasi Mari Belajar Shalat.

\section{KESIMPULAN}

Berdasarkan penelitian yang sudah dilaksanakan dari tahap Concept (Konsep), Design (Desain / Perancangan), Material Collecting (Pengumpulan Materi), Assembly (Penyusunan dan Pembuatan), Testing (Uji Coba) hingga Distribution (Menyebarluaskan), maka kesimpulan yang diperoleh adalah sebegai berikut :

1. Telah berhasil dibuat aplikasi Mari belajar shalat yang dimana bisa membantu pembelajaran gerakan shalat untuk anak usia dini.

2. Telah berhasil dibuat media pengenalan tuntunan shalat dengan objek 3 dimensi yang menggunakan teknologi Augmented Reality.

\section{UCAPAN TERIMA KASIH}

Skripsi ini tidak dapat diselesaikan dengan baik tanpa bantuan dari berbagai pihak. Oleh karena itu dalam kesempatan ini penulis mengucapkan banyak terima kasih kepada Rektor Universitas Negeri Manado, Dekan Fakultas Teknik, dan dosen-dosen Program Studi Teknik Informatika. Penulis juga mengucapkan terimakasih kepada Dosen pembimbing Akademik dan Pembimbing Skripsi. Orang tua dan Keluarga. Teman-teman angkatan 2016. 


\section{DAFTAR PUSTAKA}

[1] D. Tresnawati et al., "Pengembangan aplikasi tata cara wudhu dan shalat untuk anak menggunakan sistem multimedia," pp. 17.

[2] J. T. Informatika, F. Sains, D. A. N. Teknologi, U. Islam, and N. Syarif, "Aplikasi tuntunan shalat berbasis multimedia," 2010.

[3] H. Abdurahman and A. R. Riswaya, "Aplikasi Pinjaman Pembayaran Secara Kredit Pada Bank Yudha BHakti," Apl. Pinjaman Pembayaran Secara Kredit Pada Bank Yudha BHakti, vol. 8, no. 2, pp. 61-69, 2014, [Online]. Available: http://jurnal.stmik-mi.ac.id/index.php/jcb/article/view/114/138.
Tuntunan Shalat Menggunakan Augmented Reality Berbasis Android," e-Proceeding Appl. Sci., vol. 1, no. 3, pp. 2-5, 2012. Masjid, R. Sengkey, and S. Karouw, "Rancang Bangun Aplikasi Alat Musik Kolintang menggunakan Augmented Reality berbasis Android," vol. 7, no. 1, 2016.

[6] S. C. Riady et al., "Rancang Bangun Aplikasi Mobile Learning Anak Sekolah Minggu dengan Teknologi Augmented Reality Berbasis Android," vol. 9, no. 1, pp. 20-25, 2016.

[7] A. Science, "1 , 2,3 123," vol. 2, no. 1, pp. 211-219, 2016.

[8] D. Tresnawati, J. Algoritma, S. Tinggi, T. Garut, and S. Malam, "Pengembangan aplikasi tuntunan shalat malam menggunakan sistem multimedia," pp. 1-7.

[9] P. Teknologi et al., "Penerapan Teknologi Augmented Reality Sebagai Media Pengenalan ... (Sifana dkk)," pp. 82-88, 2015. 